\title{
Pendugaan Luas Panen dan Produksi Jagung Nasional Menggunakan Pendekatan Modeling
}

\author{
Forecasting Harvesting Area and Production of Maize \\ using Modeling Approach
}

Muhammad Aqil, Herman Subagio, N. N. Andayani dan Fahdiana Tabri

Balai Penelitian Tanaman Serealia

JI. Dr. Ratulangi 274 Maros;

Email: acchmad@yahoo.com

Diterima : 31 Januari 2019

Revisi : 19 Februari 2019

Disetujui : 13 Maret 2019

\begin{abstract}
ABSTRAK
Stabilitas produksi merupakan salah satu kendala dalam pengembangan jagung di Indonesia. Penelitian ini difokuskan pada pengembangan model untuk menduga luas panen dan produksi jagung di Indonesia menggunakan dua model yaitu Arima dan Dumped trend. Data seri waktu dikumpulkan dari periode 1960-2016. Data yang menunjukkan pola gejolak sehingga dilakukan standardisasi terlebih dahulu dengan menggunakan natural logaritma. Hasil pendugaan menunjukkan kedua model dapat memprediksi trend produksi jagung dengan nilai koefisien korelasi $>0,98$. Variabel luas panen lebih sulit diprediksi karena pola gejolak data lebih ekstrem. Nilai koefisien korelasi luas panen 0,78 dengan model Arima serta 0,74 dengan model Dumped. Hasil pengujian model menunjukkan bahwa proyeksi tingkat produksi jagung pada tahun 2036 diperkirakan luas panen jagung naik menjadi 4.512.000 ha. Hasil pendugaan produksi jagung menunjukkan adanya kenaikan produksi dari 23 juta ton pada 2017 menjadi 36 juta ton atau naik sebesar 13 juta ton. Adapun model Dumped trend menduga produksi jagung lebih tinggi yaitu 23 juta ton pada tahun 2017 dan naik menjadi 41 juta ton pada tahun 2036.

kata kunci : Arima, dumped trend, luas panen, produksi, jagung
\end{abstract}

\section{ABSTRACT}

Stability in maize production is the main obstacles in maize development in Indonesia. The research focused on the development of a model for estimating harvested area and corn production in Indonesia using Arima and Dumped trend model. Time series data was derived from the period of 1960 to 2016. Data was first standardized using natural logarithms. The results indicated that both models provide sufficient accuracy in predicting maize yield with correlation coefficient $>0.98$. Meanwhile, the trend of harvested area is more difficult to predict because the data series more chaotic. The correlation coefficient of harvested area was 0.78 and 0.74 by Arima and Dumped model respectively. The results of model testing show that the projection of maize area in 2036 is estimated to increase to 4,512,000 ha. Meanwhile maize production forecast shows production increase from 23 million tons in 2017 to 36 million tons or increased by 13 million tons. Meanwhile the Dumped trend estimates maize production relatively higher i.e. 23 million tons in 2017 and rises to 41 million tons in 2036.

keywords: Arima, dumped trend, harvest area, production, maize

\section{PENDAHULUAN}

lagung merupakan salah satu komoditas pangan penting di Indonesia setelah padi.
Kontribusi tanaman jagung terhadap produk domestik bruto (PDB) nasional terus meningkat setiap tahun. Penelitian ini 
menggunakan data sekunder terkait luas tanam dan produksi nasional. PDB jagung meningkat drastis seiring meningkatnya perhatian pemerintah untuk mewujudkan swasembada jagung. Pada tahun 2014 PDB jagung mencapai $R p 42$ triliun dan nilai ini terus meningkat sekitar 1,2 persen setiap tahunnya (Pusdatin, 2016; Pusdatin, 2017).

Wilayah produksi jagung di Indonesia juga mengalami pergeseran, baik antar pulau maupun antar provinsi. Pada periode 1990-an produsen utama jagung adalah provinsi Jawa Timur, Jawa Tengah, Lampung, Sulawesi Selatan dan Nusa Tenggara Timur, namun pada tahun 2015 provinsi penghasil jagung terbanyak adalah Jawa Timur, Jawa Tengah, Sulawesi Selatan, Sumatera Utara dan Lampung (BPS, 2016). Pola penyediaan jagung juga mengalami perubahan yang signifikan, yaitu pada era 1990-an sebanyak 67 persen jagung dihasilkan di pulau Jawa dan sisanya 33 persen di luar Jawa, sedangkan pada tahun 2015, pangsa produksi jagung Jawa menurun menjadi 49 persen dan luar Jawa 51 persen (Sulaiman, dkk., 2017).

Seiring perkembangan industri pakan, kebutuhan jagung juga meningkat sehingga pemerintah melakukan impor dengan nilai fluktuatif. Impor jagung mencapai puncak pada tahun 2011, yaitu sebanyak 2.500 .000 ton (Darsana, 2012). Dengan adanya kebijakan pemerintah untuk mendorong produksi jagung dalam negeri, nilai impor jagung kemudian berkurang secara signifikan, khususnya sejak program upaya khusus (upsus) jagung diluncurkan (Ditjen PSP, 2017). Permintaan jagung dalam negeri sifatnya stokastik dan jumlahnya berfluktuasi mengikuti fluktuasi permintaan industri pakan ternak ayam pedaging dan ayam petelur.

Beragam metode telah dikembangkan untuk memprediksi trend atau pola dari suatu seri data dengan menggunakan pencatatan data sebelumnya. Di antara metode yang banyak digunakan adalah metode regresi (Magar dan Jothiprakash, 2011; Murugan dan Manivel, 2009), metode fuzzy (Tsaur, 2012; Egrioglu, 2009; Cheng, dkk., 2011), metode jaringan urat saraf (Sharda dan Patil (1992); Matsumura, dkk., 2014), metode exponential smoothing (Nurmaulidar, dkk., 2016), model Garch (Zheng, dkk., 2008; Musunuru, dkk.,
2013) serta Arima (Okasha, dkk., 2014; Fatoki, dkk., 2010). Di antara metode tersebut yang paling banyak digunakan saat ini adalah metode Arima yang dikembangkan oleh BobJenkins. Data seri waktu yang umumnya digunakan dalam pendugaan adalah data tahunan, data bulanan, harian serta data sub round.

Penelitian ini bertujuan untuk memodelkan luas panen dan produksi jagung nasional dengan cara memasukkan unsur keheterogenan ragam data menggunakan dua model yaitu Arima dan Dumped Trend. Modelmodel tersebut dibandingkan dan dievaluasi, kemudian yang paling tepat dipilih untuk mendapatkan hasil yang dapat memprediksi luas panen dan produksi jagung ke depan dengan akurasi tinggi.

\section{METODOLOGI}

Penelitian ini menggunakan data sekunder terkait luas tanam dan produksi nasional. Data diperoleh dari Badan Pusat Statistik (BPS), Direktorat Jenderal Tanaman Pangan, Balai Penelitian Tanaman Serealia serta buku statistik nasional. Rentang waktu yang digunakan adalah data produksi jagung tahunan dengan rentang periode tahun 1960 sampai tahun 2016. Variabel terikat (dependent) dalam penelitian ini adalah luas panen (ha) serta produksi jagung tahunan (ton) sedangkan variable bebas (independent) adalah waktu (tahun). Data dianalisis dengan menggunakan dua model yaitu Model Arima yang diperkenalkan oleh Bob dan Jenkins pada tahun 1976, serta model Dumped Trend yang pertama kali diperkenalkan oleh Gardner dan McKenzie pada tahun 1985. Kedua model tersebut telah diterapkan dalam berbagai analisis permasalahan terkait analisis rentang waktu.

\subsection{Model Autoregressive Integrated Moving Average (Arima)}

Salah satu model seri waktu yang paling banyak digunakan saat ini adalah model Arima. Model Arima ( $p, d, q)$ merupakan kombinasi antara model autoregresi (Ar) dan moving average (Ma). Model autoregresi menunjukkan adanya hubungan antara nilai saat ini $(Z)$ dengan nilai sebelumnya $\left(Z_{t-k}\right)$ ditambah dengan adanya koefisien acak/random. Adapun model moving average 
menunjukkan adanya hubungan antara nilai saat ini $\left(Z_{t}\right)$ dengan residual/sisa sebelumnya

$$
\left(Z_{t-k} \quad k=1,2 \ldots\right)
$$

Dengan pola data yang tidak stasioner dan perbedaan orde $d$ maka model Arima (p, d, q) dirumuskan sebagai berikut:

$\Phi_{\mathrm{p}}(B)(1-B)^{d} Z_{\mathrm{t}}=\theta_{\mathrm{q}}(\mathrm{B}) \mathrm{a}$

Keterangan :

$$
\begin{aligned}
\mathrm{p} & =\text { orde model } \mathrm{Ar} \\
\mathrm{q} & =\text { orde model } \mathrm{Ma} \\
d & =\text { beda orde }
\end{aligned}
$$

$\Phi_{p}(B)=\left(1-\Phi_{1} B-\Phi_{2} B^{2}-\ldots-\Phi_{p} B^{p}\right)$ $\Phi_{p}(B)=\left(1-\Phi_{1} B-\Phi_{2} B^{2}-\ldots-\Phi_{q} B^{q}\right)$

Generalisasi model Arima untuk pola data musiman dituliskan sebagai berikut:

$$
\begin{aligned}
& \operatorname{ARIM}(p, d, q)(P, D, Q)^{2}= \\
& \Phi_{p}(B) \Phi_{p}\left(B^{2}\right)(1-B)^{d}\left(1-B^{s}\right)\left(1-B^{s}\right)^{D} \\
& Z_{t} \\
& =\theta_{q}(B)^{\ominus} Q\left(B^{s}\right) a_{t}
\end{aligned}
$$

Keterangan s merupakan periode musiman

$$
\begin{aligned}
& \Phi_{p}\left(B^{s}\right)=\left(1-\Phi_{1} B-\Phi_{2} B^{2}-\right. \\
& \left.\ldots-\Phi_{p} B^{p}\right) \\
& \Phi \theta_{q}(B)=\left(1-\theta_{1} B-\theta_{2} B^{2}-\right. \\
& \left.\ldots-\theta_{q} B^{q}\right)
\end{aligned}
$$

Untuk menentukan apakah data yang digunakan sudah bersifat stasioner atau belum kriteria yang umum digunakan adalah nilai ACF atau autocorrelation. Model untuk seri waktu data yang tidak stasioner dinamakan Autoregressive Integrated Moving Average model atau Arima ( $p, d, q)$. Nilai $p$ menunjukkan urutan dari bagian autoregresi, $\mathrm{d}$ menunjukkan jumlah selisih rataan dan q menunjukkan urutan/order bagian moving average. sebagai

Perbedaan operasi linear $(\boldsymbol{\Delta})$ dirumuskan

$$
\Delta Y_{t}=Y_{t}-Y_{t-1}=Y_{t}-B Y_{t}=(1-B) Y_{t}
$$

Seri stasioner dirumuskan sebagai berikut:

$$
\begin{aligned}
& W_{t}=\Delta^{d} Y_{t}=(1-B)^{d} Y_{t}=\mu+\theta_{q}(B) \varepsilon_{t} \\
& \operatorname{or} \Phi_{p}(B) W_{t}=\mu+\theta_{q}(B) \varepsilon_{t}
\end{aligned}
$$

\subsection{Model Dumped Trend}

Dalam analisis trend dilakukan penyesuaian terhadap level dan slope melalui penambahan faktor damping. Persamaan
Damped trend yang telah dimasukkan faktor damping adalah sebagai berikut.

$L_{t}=L_{t-1}+\Phi B_{t-1}+\alpha e_{t}$

$\mathrm{B}_{\mathrm{t}}=\Phi \mathrm{B}_{\mathrm{t}-1}+\alpha \beta \mathrm{e}_{\mathrm{t}}$

Keterangan :

$$
\begin{aligned}
& \mathrm{Lt}=\text { tingkatan seri waktu } \mathrm{t} \\
& \mathrm{Bt}=\text { slope dari seri waktu } \mathrm{t} \\
& \mathrm{e}=\text { random error } \\
& \alpha=\text { Konstanta untuk smoothing } \\
& \text { model } \\
& \Phi= \text { faktor damping (berkisar antara } \\
&0-1)
\end{aligned}
$$

Dalam kasus ini, nilai teta yang digunakan adalah nilai positif (kurang dari 1) sehingga akan menggeser slope hingga mendekati angka nol atau damping. Fungsi peramalan akhir pada lag waktu (time step) akan menjadi:

$F_{t+h l t}=L_{t}+\left(\Phi+\Phi^{2}+\ldots . .+\Phi^{h}\right) B_{t}$

\subsection{Uji Keandalan Model}

Estimasi parameter model Arima dan damped trend diuji kelayakannya dengan mempertimbangkan sifat dari residu apakah bersifat normal atau terdistribusi secara acak. Uji kelayakan model dilakukan dengan menggunakan uji Ljung-Box Q (Enders, 2004). Statistik uji $Q$ dinyatakan sebagai berikut

$Q_{m=n(n+2)} \sum_{k-1}^{n} \underset{n-k}{r_{k}^{2}(e)} \quad X_{m-r}^{2}$

Keterangan:

$$
\begin{array}{ll}
r_{k}(e) & =\text { residu autokorelasi lag } \mathrm{k} \\
\mathrm{n} & =\text { jumlah residual } \\
\mathrm{m} & =\text { jumlah lag waktu yang diuji }
\end{array}
$$

Apabila nilai $p$-value berkaitan dengan statistik $Q$ bernilai kecil ( $p$-value $<\alpha)$ maka model dianggap layak. Analisis harus mempertimbangkan model baru atau modifikasi model sampai model optimal didapatkan. Selain uji derajat signifikansi Ljung-Box, parameter lain yang juga dijadikan acuan kelayakan model adalah nilai mean average percentage error (MAPE), mean absolute error (MAE), $R$ squared dan beberapa parameter lainnya.

\section{HASIL DAN PEMBAHASAN}

Data seri waktu yang digunakan dalam training model adalah data produksi jagung nasional periode 1960-2016 yang telah dikeluarkan oleh BPS (2016). Kisaran nilai seri 
waktu luas panen minimum adalah 2.010 .000 ha (tahun 1962) dan tertinggi 4.440 .000 ha

\subsection{Penetapan Parameter Model}

Tabel 1. Parameter untuk Model Fit Luas Panen Jagung Nasional

\begin{tabular}{lrllc}
\hline \multirow{2}{*}{ Fit statistic } & \multicolumn{4}{c}{ ARIMA Ljung-Box Q } \\
\cline { 2 - 6 } Stationary R- & Mean & Statistics & DF & Sig \\
squared & 0,201 & 11,624 & 14 & 0,603 \\
r-squared & 0,967 & 11,624 & 14 & 0,603 \\
RSME & $1,099 E 6$ & 11,624 & 14 & 0,603 \\
MAPE & 12,260 & 11,624 & 14 & 0,603 \\
MaxAPE & 59,821 & 11,624 & 14 & 0,603 \\
MAE & $8,314 \mathrm{E} 5$ & 11,624 & 14 & 0,603 \\
MaxAE & $3,359 E 6$ & 11,624 & 14 & 0,603 \\
Normalized BIC & 28,184 & 11,624 & 14 & 0,603 \\
\hline
\end{tabular}

(tahun 2016) dengan rata-rata luas panen Analisis data dilakukan dengan

setiap tahunnya 3.122.816 ha dengan standar deviasi sebesar 620.751 ha. Adapun parameter produksi jagung berkisar antara 2.280.000 ton (tahun 1962) dan tertinggi 23.600.000 ton (tahun 2016), dengan rata-rata produksi selama periode 1960-2016 adalah 7.603.375 ton dengan standar deviasi sebesar 5.488 .463 ton.
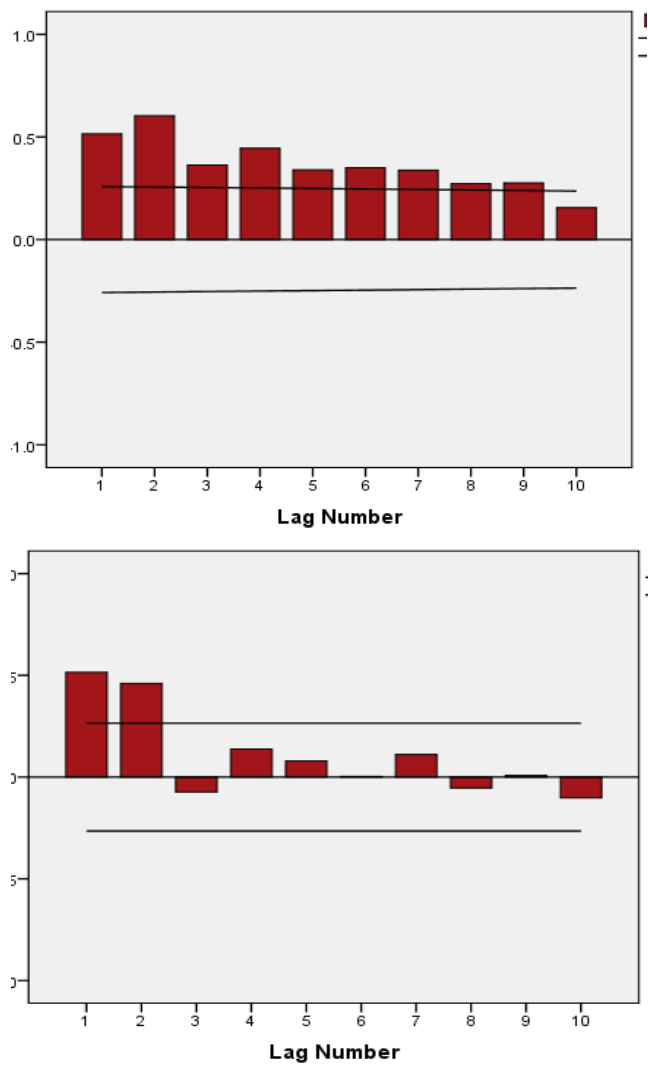

Gambar 1. Fungsi Autokorelasi dan Parsial Autokorelasi dari Luas Areal Panen
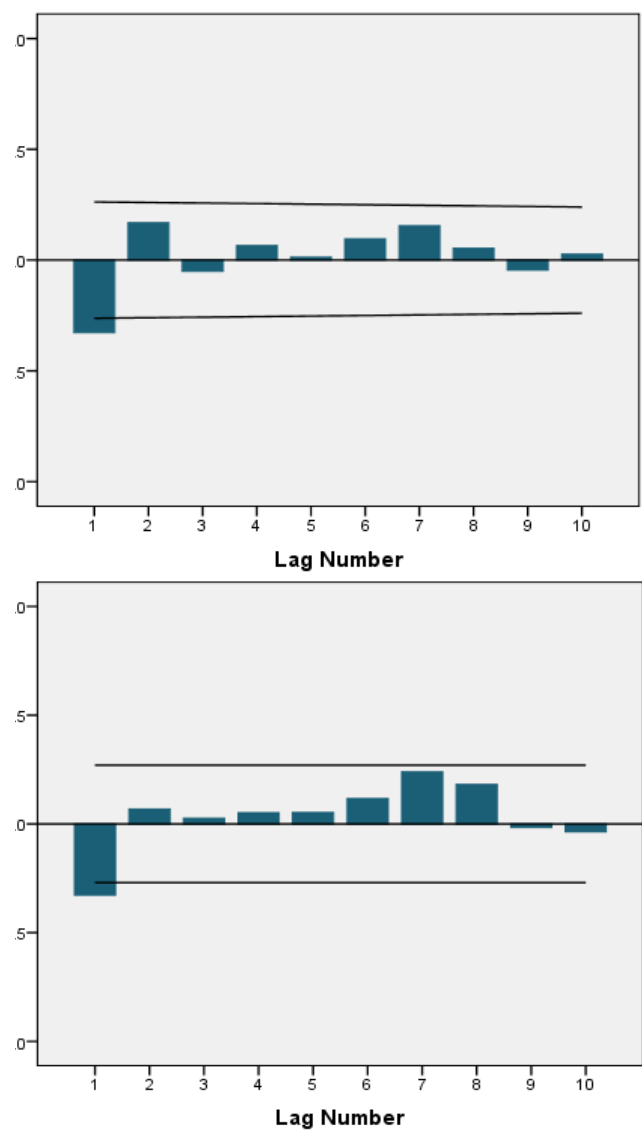

Gambar 2. Fungsi Autokorelasi dan Parsial Autokorelasi Produksi Jagung

menggunakan dua model yaitu Model Arima yang diperkenalkan oleh Bob dan Jenkins serta model Dumped Trend. Pada model Arima, penetapan parameter model menggunakan pendekatan nilai autokorelasi (ACF) dan parsial autokorelasi (PACF) (Makridakis, dkk., 1999). Fungsi ACF 
menunjukkan urutan bahan auto regresi " $q$ " dari model sedangkan PACF akan mengidentifikasi ada atau tidaknya sifat AR autoregresif, yang dinotasikan dengan besaran " $p$ ".
Dumped dengan nilai sebesar 0,55. Nilai korelasi yang tinggi menunjukkan bahwa model mampu memodelkan gejolak data secara baik. Rata-rata penyimpangan model dalam menduga luas panen jagung antara 22-

Tabel 2. Parameter untuk Model Produksi Jagung Nasional

\begin{tabular}{lrrrrrrrr}
\hline \multirow{2}{*}{ Fit Statistic } & \multicolumn{3}{c}{ Arima Ljung-Box Q } & \multicolumn{3}{c}{ Dumped Ljung-Box Q } \\
\cline { 2 - 9 } & \multicolumn{1}{c}{ Mean } & Statistics & DF & Sig & Mean & Statistics & DF & Sig \\
\hline Stationary R- & 0,201 & 11,624 & 14 & 0,603 & 0,217 & 12,190 & 15 & 0,665 \\
squared & 0,967 & 11,624 & 14 & 0,603 & 0,965 & 12,190 & 15 & 0,665 \\
r-squared & $1,099 E 6$ & 11,624 & 14 & 0,603 & $1,057 \mathrm{E} 6$ & 12,190 & 15 & 0,665 \\
RSME & 12,260 & 11,624 & 14 & 0,603 & 13,191 & 12,190 & 15 & 0,665 \\
MAPE & 59,821 & 11,624 & 14 & 0,603 & 42,048 & 12,190 & 15 & 0,665 \\
MaxAPE & $8,314 E 5$ & 11,624 & 14 & 0,603 & $8,107 \mathrm{E} 5$ & 12,190 & 15 & 0,665 \\
MAE & 3,359E6 & 11,624 & 14 & 0,603 & $3,136 \mathrm{E} 6$ & 12,190 & 15 & 0,665 \\
MaxAE & & & & & & & &
\end{tabular}

Diagram fungsi autokorelasi dan parsial autokorelasi dari luas areal panen dan produksi jagung dapat dilihat pada Gambar 1 dan 2. Berdasarkan nilai perbedaan maka fungsi ACF menurun setelah lag 2 pada luas panen dan 1 pada model produksi sehingga nilai parameter q ditetapkan masing-masing 2 dan 1. lqbal, dkk. (2014) menyatakan uji ACF dan PACF mampu mendeteksi stasioner data dari nilai rataan. Demikian pula fungsi PACF pada luas panen dan produksi masing-masing menunjukkan nilai $p$ yaitu 2 dan 1 sehingga model Arima yang diterapkan adalah Arima $(2,1,2)$ untuk luas panen dan Arima $(1,1,1)$ untuk produksi jagung.

25 persen. Parameter lain yang menentukan kelayakan model adalah nilai koefisien signifikansi Ljung-Box. Nilai ini umumnya dijadikan dasar untuk menilai layak tidaknya sebuah model diaplikasikan. Nilai Ljung-Box $>0,05$ menunjukkan model yang layak digunakan. Berdasarkan hasil uji model fit diperoleh nilai parameter Ljung-Box Arima sebesar 0,505 dan Dumped sebesar 0,3 $(>0,05)$ sehingga model dapat digunakan untuk analisis trend luas panen jagung.

Selanjutnya dilakukan estimasi parameter model pada Arima dan Dumped trend. Pada model Arima, parameter AR dan MA pada variabel luas pertanaman yang dipanen serta

Tabel 3. Estimasi Parameter Luas Pertanaman dan Produksi Jagung Model Arima

\begin{tabular}{llllllll}
\hline \multicolumn{3}{c}{ Luas pertanaman } & \multicolumn{3}{c}{ Produksi } \\
\hline Tipe & Koefisien & SE & t rasio & Tipe & Koefisien & SE & t rasio \\
\hline AR1 & $-1,122$ & 0,147 & $-7,610$ & AR1 & $-1,177$ & 0,137 & $-8,584$ \\
AR2 & $-0,284$ & 0,147 & $-1,937$ & MA1 & 0,993 & 0,262 & 0,642 \\
MA1 & 0,999 & 7,149 & 9,149 & & & & \\
MA2 & 0,318 & 2,868 & 0,111 & & & & \\
\hline
\end{tabular}

Pengujian model Arima dan Dumped trend exponential smoothing memperlihatkan nilai parameter model fit yang cukup baik seperti pada pemodelan luas panen (Tabel 1) dan pemodelan produksi jagung (Tabel 2). Perhitungan galat error data dilakukan dengan memasukkan nilai forecast (yang juga merupakan nilai peramalan) bersama dengan nilai aktual ke dalam persamaan $R$-square, MAPE, MAE. Nilai koefisien determinasi luas panen menggunakan model Arima adalah 0,62 , yang lebih baik dibandingkan model produksi jagung dapat dilihat pada Tabel 3. Setelah melalui proses differencing maka diperoleh nilai koefisien AR1, AR2, MA1 dan MA2 signifikan dengan nilai $p$-value $<0,05$ pada parameter luas panen dan produksi jagung. Hal ini mengindikasikan model cukup baik dan dapat diproses lebih lanjut untuk pendugaan panen dan tingkat produksi jagung.

Estimasi parameter pada model Dumped trend disajikan pada Tabel 4. Hasil uji Pendugaan Luas Panen dan Produksi Jagung Nasional Menggunakan Pendekatan Modeling Muhammad Aqil, Herman Subagio, N. N. Andayani dan Fahdiana Tabri 
signifikansi menunjukkan nilai koefisien alpha, gamma dan phi yang cukup baik sehingga model dapat diteruskan untuk menduga adanya trend produksi serta nilai proyeksi ke depannya.
Kendala gejolak data telah diminimalkan dengan melakukan transformasi data menggunakan transformasi logaritma, sebelum dilakukan pendugaan (Aqil, dkk., 2007). Kendala lain adalah penetapan parameter $p$ dan $q$ yang harus dilakukan trial

Tabel 4. Estimasi Parameter Luas Pertanaman dan Produksi Jagung Model Dumped

\begin{tabular}{lrrrlcrr}
\hline & \multicolumn{2}{c}{ Luas pertanaman } & & \multicolumn{4}{c}{ Produksi } \\
\hline Tipe & Koefisien & SE & T rasio & Tipe & $\begin{array}{c}\text { Koefisie } \\
\mathbf{n}\end{array}$ & SE & t rasio \\
\hline Alpha & 0,071 & 0,084 & 0,851 & Alpha & 0,400 & 0,121 & 3,319 \\
Gamma & $9,203 \mathrm{E}-7$ & 0,056 & $1,64 \mathrm{E}-5$ & Gamma & 0,200 & 0,206 & 0,972 \\
Phi & 1,000 & 0,009 & 112,722 & Phi & 0,999 & 0,076 & 13,186 \\
\hline
\end{tabular}

\subsection{Penetapan Luas Panen dan Produksi Jagung Eksisting}

Gambar 3 memperlihatkan diagram skater dari data aktual luas panen dengan produksi jagung serta nilai hasil ramalan/dugaan. Pada setiap diagram, nilai ramalan yang baik akan berada pada garis dengan kemiringan $45^{\circ}$ (Aqil, dkk., 2007).

Hasil pengamatan menunjukkan bahwa model dapat memprediksi hasil dengan baik saat trend luas tanam dan panen bersifat kontinu. Namun demikian, model mengalami overestimate atau nilai luas panen atau produksi mengalami peningkatan yang tajam. Kenaikan luas panen dan produksi umumnya terjadi pada awal musim hujan (NovemberApril) yang nilainya mencapai 70 persen dari total produksi, di samping faktor iklim/hujan yang tersedia serta tidak adanya gangguan OPT (Sulaiman, dkk., 2017).

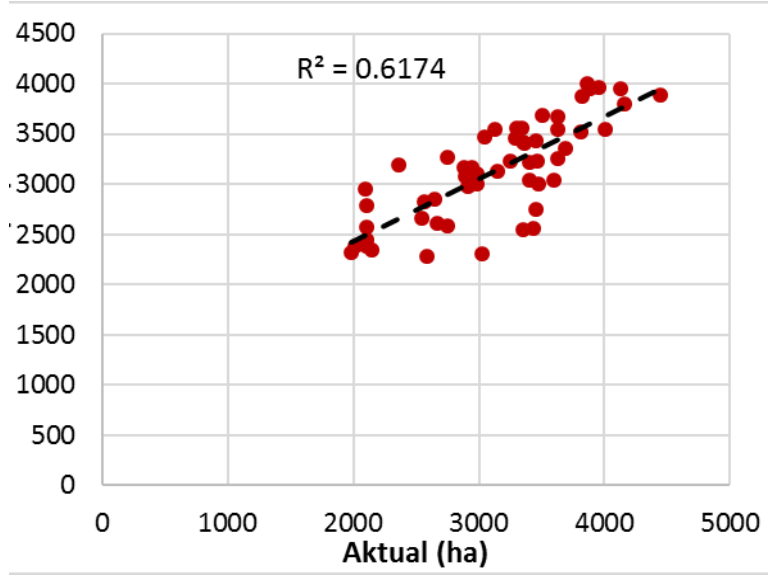

dan error sebagai pembanding fungsi hasil autokorelasi dan parsial autokorelasi. Koefisien determinasi data luas tanam yang diperoleh sebesar 0,617, tergolong cukup rendah akibat pola data yang menunjukkan gejolak yang tinggi. Adapun koefisien determinasi data produksi jagung sebesar 0,962 , tergolong baik karena parameter model yang dipilih mampu memprediksi pola gejolak dengan lebih baik.

Plot seri waktu trend luas tanam jagung menggunakan model Arima serta produksi menggunakan Dumped trend dapat dilihat pada Gambar 4 dan 5. Data seri waktu menunjukkan trend angka prediksi luas panen jagung terhadap data aktual. Walaupun model dapat memprediksi trend peningkatan luas tanam, namun pada waktu tertentu model kadangkala mengalami peningkatan yang tajam sesuai dengan prediksi produksi tahun 1973, 1976 dan tahun 1984, serta

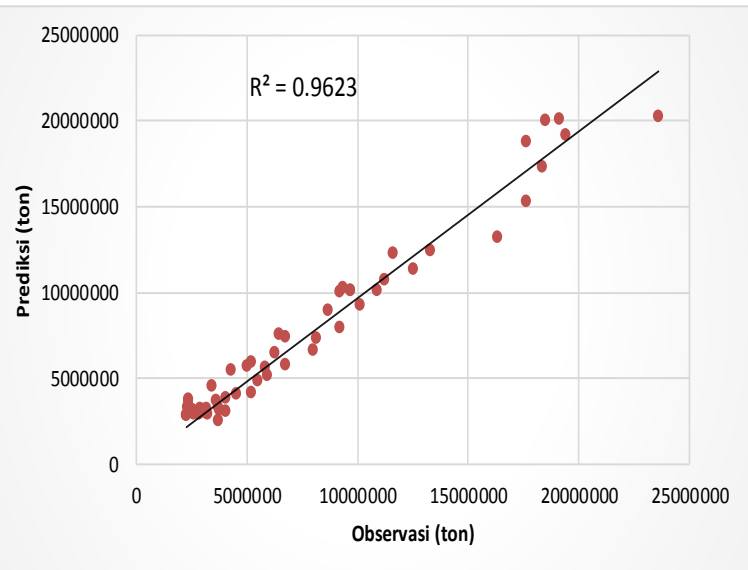

Gambar 3. Diagram Skater Plot Data Aktual Dengan Data Ramalan Luas Panen (Kiri) dan Produksi Jagung (Kanan)

underestimate atau mengalami penurunan 
yang tajam pada tahun 1979, 1980, 1997 dan 2016 di mana perbedaan antara nilai aktual dan prediksi cukup besar. Hal ini sesuai dengan hasil yang diperoleh oleh Badmus dan Ariyo, 2011 yang menggunakan model ARIMA $(2,1,2)$ untuk menduga trend produksi jagung di Nigeria di mana pada kondisi tertentu data

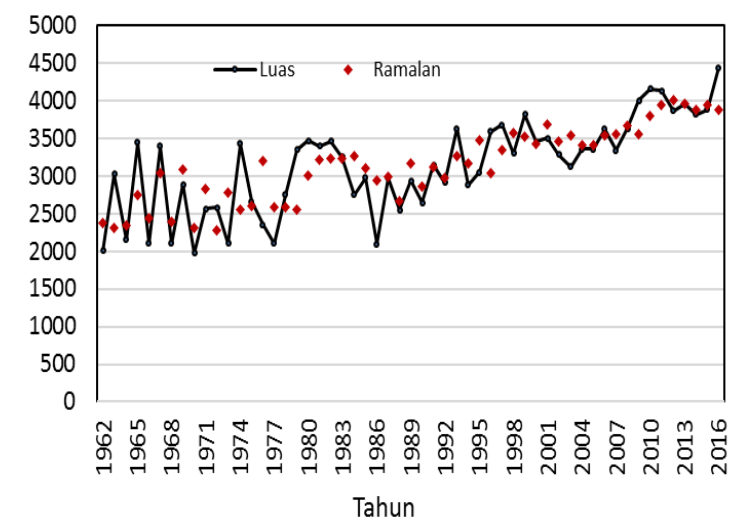

Gambar 4. Plot Seri Waktu Trend Luas

Tanam Jagung Menggunakan Model Arima

mengalami pergerakan ekstrem dan sulit untuk diprediksi sehingga menimbulkan peningkatan secara tajam.
Nilai koefisien korelasi memprediksi luas tanam menggunakan model Arima $=0,78$, sedangkan model Dumped trend korelasinya lebih rendah yaitu 0,74. Ranđelović, dkk. (2010) menyatakan penurunan produksi umumnya diakibatkan oleh faktor kekeringan/ketersediaan air yang rendah. Selain itu pola luas panen jagung yang

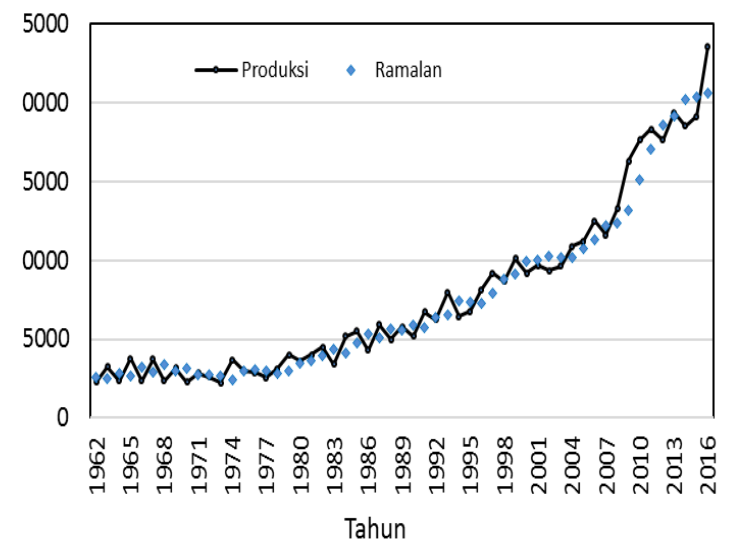

Gambar 5. Plot Seri Waktu Produksi Jagung Menggunakan Model Dumped Trend

terfokuskan pada periode tertentu dan kemudian menurun secara tajam menyulitkan model dalam memprediksi nilai ke depannya.

Tabel 5. Proyeksi Trend Luas Panen Jagung Nasional Periode 2017-2036

\begin{tabular}{ccccccc}
\hline & \multicolumn{3}{c}{ Model Arima } & \multicolumn{3}{c}{ Model Dumped Trend } \\
\cline { 2 - 7 } Tahun & $\begin{array}{c}\text { Luas } \\
\text { panen (ha) }\end{array}$ & $\begin{array}{c}\text { Batas bawah } \\
\text { (ha) }\end{array}$ & $\begin{array}{c}\text { Batas } \\
\text { atas (ha) }\end{array}$ & $\begin{array}{c}\text { Luas } \\
\text { panen (ha) }\end{array}$ & $\begin{array}{c}\text { Batas bawah } \\
\text { (ha) }\end{array}$ & $\begin{array}{c}\text { Batas } \\
\text { atas (ha) }\end{array}$ \\
\hline 2017 & 4.020 .037 & 3.247 .125 & 4.814 .089 & 3.989 .576 & 3.122 .574 & 4.856 .578 \\
2018 & 4.030 .607 & 3.445 .549 & 5.025 .514 & 4.018 .401 & 3.149 .196 & 4.887 .605 \\
2019 & 4.235 .532 & 3.140 .448 & 4.891 .401 & 4.047 .225 & 3.175 .824 & 4.918 .627 \\
2020 & 4.015 .924 & 3.306 .727 & 5.057 .319 & 4.076 .050 & 3.202 .456 & 4.949 .643 \\
2021 & 4.182 .023 & 3.164 .501 & 4.960 .874 & 4.104 .874 & 3.229 .095 & 4.980 .654 \\
2022 & 4.062 .688 & 3.290 .982 & 5.087 .789 & 4.133 .699 & 53.255 .739 & 5.011 .659 \\
2023 & 4.189 .385 & 3.220 .684 & 5.033 .099 & 4.162 .523 & 3.282 .388 & 5.042 .659 \\
2024 & 4.126 .892 & 3.316 .584 & 5.129 .003 & 4.191 .348 & 3.309 .042 & 5.073 .653 \\
2025 & 4.222 .793 & 3.284 .886 & 5.103 .619 & 4.220 .172 & 3.335 .702 & 5.104 .642 \\
2026 & 4.194 .253 & 3.359 .083 & 5.177 .370 & 4.248 .997 & 3.362 .367 & 5.135 .626 \\
2027 & 4.268 .226 & 3.350 .111 & 5.171 .267 & 4.277 .821 & 3.389 .038 & 5.166 .605 \\
2028 & 4.260 .689 & 3.409 .420 & 5.229 .978 & 4.306 .646 & 3.415 .713 & 5.197 .578 \\
2029 & 4.319 .699 & 3.414 .465 & 5.236 .416 & 4.335 .470 & 3.442 .394 & 5.228 .546 \\
2030 & 4.325 .441 & 3.463 .765 & 5.285 .143 & 4.364 .295 & 3.469 .080 & 5.259 .509 \\
2031 & 4.374 .454 & 3.477 .668 & 5.299 .734 & 4.393 .119 & 3.495 .771 & 5.290 .467 \\
2032 & 4.388 .701 & 3.520 .323 & 5.341 .900 & 4.421 .943 & 3.522 .467 & 5.321 .420 \\
2033 & 4.431 .111 & 3.539 .898 & 5.361 .796 & 4.450 .768 & 3.549 .168 & 5.352 .368 \\
2034 & 4.450 .847 & 3.578 .174 & 5.399 .670 & 4.479 .592 & 3.575 .874 & 5.383 .311 \\
2035 & 4.488 .922 & 3.601 .407 & 5.423 .022 & 4.508 .417 & 3.602 .585 & 5.414 .249 \\
2036 & 4.512 .214 & 3.636 .812 & 5.458 .094 & 4.537 .241 & 3.629 .301 & 5.445 .182 \\
\hline
\end{tabular}

Pendugaan Luas Panen dan Produksi Jagung Nasional Menggunakan Pendekatan Modeling Muhammad Aqil, Herman Subagio, N. N. Andayani dan Fahdiana Tabri 
Angka perkiraan produksi jagung dengan menggunakan model Arima dan Dumped trend menghasilkan nilai dugaan yang lebih baik dibandingkan angka prediksi luas panen. Perbedaan nilai aktual dan prediksi lebih rendah ditunjukkan oleh koefisien korelasi yang tinggi, yaitu 0,98 pada model Arima dan 0,97 pada model Dumped trend. Trend peningkatan produksi jagung yang naik secara proporsional setiap tahunnya menghasilkan data seri waktu yang tidak bergejolak sehingga prediksi bisa dilakukan dengan lebih akurat.

\subsection{Proyeksi Luas dan Produksi Jagung 2017-2036}

Model Arima dan Dumped trend dianalisis lebih lanjut untuk memprediksi trend luas panen dan produksi jagung tahun 20172036 dengan asumsi parameter model tetap (Tabel 5). Tabel 5 menunjukkan kedua model memperlihatkan adanya kenaikan luas panen selama periode tersebut sebesar 510.000 ha yang diperoleh dari adanya perluasan areal panen jagung naik menjadi 4.512 .000 ha. Sementara itu hasil perkiraan produksi jagung menggunakan Arima (Tabel 6) menunjukkan adanya kenaikan produksi dari 23 juta ton pada 2017 menjadi 37 juta ton pada tahun 2036 atau naik sebesar 13 juta ton. Model Dumped trend (Tabel 6) menduga produksi jagung lebih tinggi yaitu 23 juta ton pada tahun 2017 dan naik menjadi 41 juta ton pada tahun 2036. Nilai ini dapat dilampaui mengingat saat ini pemerintah tengah menggalakkan program Upsus jagung, PATB di lahan perkebunan serta program serasi untuk optimalisasi potensi lahan rawa di Sumatera dan Kalimantan (Sulaiman, dkk., 2017). Pemerintah juga telah melakukan program regenerasi petani dengan menerbitkan Permentan Nomor 33/PER/SM.060/I/07/2017 untuk mendorong partisipasi petani muda dalam pengembangan areal tanam jagung, dan modernisasi pertanian (Kementerian Pertanian, 2016).

Tabel 6. Proyeksi Trend Luas Panen Jagung Nasional Periode 2017-2036

\begin{tabular}{ccccccc}
\hline Tahun & \multicolumn{3}{c}{ Model ARIMA } & \multicolumn{3}{c}{ Model Dumped } \\
\cline { 2 - 7 } & $\begin{array}{c}\text { Luas panen } \\
\text { (ha) }\end{array}$ & $\begin{array}{c}\text { Batas bawah } \\
\text { (ha) }\end{array}$ & $\begin{array}{c}\text { Batas } \\
\text { atas (ha) }\end{array}$ & $\begin{array}{c}\text { Luas } \\
\text { panen (ha) }\end{array}$ & $\begin{array}{c}\text { Batas bawah } \\
\text { (ha) }\end{array}$ & $\begin{array}{l}\text { Batas } \\
\text { atas (ha) }\end{array}$ \\
\hline 2017 & 4.020 .037 & 3.247 .125 & 4.814 .089 & 3.989 .576 & 3.122 .574 & 4.856 .578 \\
2018 & 4.030 .607 & 3.445 .549 & 5.025 .514 & 4.018 .401 & 3.149 .196 & 4.887 .605 \\
2019 & 4.235 .532 & 3.140 .448 & 4.891 .401 & 4.047 .225 & 3.175 .824 & 4.918 .627 \\
2020 & 4.015 .924 & 3.306 .727 & 5.057 .319 & 4.076 .050 & 3.202 .456 & 4.949 .643 \\
2021 & 4.182 .023 & 3.164 .501 & 4.960 .874 & 4.104 .874 & 3.229 .095 & 4.980 .654 \\
2022 & 4.062 .688 & 3.290 .982 & 5.087 .789 & 4.133 .699 & 53.255 .739 & 5.011 .659 \\
2023 & 4.189 .385 & 3.220 .684 & 5.033 .099 & 4.162 .523 & 3.282 .388 & 5.042 .659 \\
2024 & 4.126 .892 & 3.316 .584 & 5.129 .003 & 4.191 .348 & 3.309 .042 & 5.073 .653 \\
2025 & 4.222 .793 & 3.284 .886 & 5.103 .619 & 4.220 .172 & 3.335 .702 & 5.104 .642 \\
2026 & 4.194 .253 & 3.359 .083 & 5.177 .370 & 4.248 .997 & 3.362 .367 & 5.135 .626 \\
2027 & 4.268 .226 & 3.350 .111 & 5.171 .267 & 4.277 .821 & 3.389 .038 & 5.166 .605 \\
2028 & 4.260 .689 & 3.409 .420 & 5.229 .978 & 4.306 .646 & 3.415 .713 & 5.197 .578 \\
2029 & 4.319 .699 & 3.414 .465 & 5.236 .416 & 4.335 .470 & 3.442 .394 & 5.228 .546 \\
2030 & 4.325 .441 & 3.463 .765 & 5.285 .143 & 4.364 .295 & 3.469 .080 & 5.259 .509 \\
2031 & 4.374 .454 & 3.477 .668 & 5.299 .734 & 4.393 .119 & 3.495 .771 & 5.290 .467 \\
2032 & 4.388 .701 & 3.520 .323 & 5.341 .900 & 4.421 .943 & 3.522 .467 & 5.321 .420 \\
2033 & 4.431 .111 & 3.539 .898 & 5.361 .796 & 4.450 .768 & 3.549 .168 & 5.352 .368 \\
2034 & 4.450 .847 & 3.578 .174 & 5.399 .670 & 4.479 .592 & 3.575 .874 & 5.383 .311 \\
2035 & 4.488 .922 & 3.601 .407 & 5.423 .022 & 4.508 .417 & 3.602 .585 & 5.414 .249 \\
2036 & 4.512 .214 & 3.636 .812 & 5.458 .094 & 4.537 .241 & 3.629 .301 & 5.445 .182 \\
\hline
\end{tabular}

tanam baru serta peningkatan IP melalui penyediaan embung dan dam parit berukuran kecil untuk mendukung pertanaman, khususnya pada musim kemarau (Ditjen PSP, 2016). Pada tahun 2036 diperkirakan luas

\section{KESIMPULAN}

Model Arima memprediksi variabel luas tanam dan produksi lebih baik dibandingkan model Dumped. Nilai korelasi luas panen 
dengan model Arima mencapai 0,78 sedangkan model Dumped lebih rendah yaitu 0,74 . Korelasi produksi nilainya lebih tinggi yaitu $>0,95$. Variabel luas tanam mempunyai seri data yang sangat variatif atau bergejolak sehingga menyulitkan pendugaan secara akurat. Variabel produksi dapat diprediksi lebih akurat karena trend kenaikan setiap tahunnya bersifat positif. Namun demikian untuk meningkatkan akurasi model diperlukan pemodelan berdasarkan fluktuasi data bulanan atau sub round.

\section{UCAPAN TERIMA KASIH}

Terima kasih kami sampaikan kepada BPS yang telah menyiapkan data sekunder serta Kementerian Pertanian yang atas pendanaan untuk pelaksanaan penelitian.

\section{Daftar Pustaka}

Aqil, M., I. Kita, A. Yano, S. Nishiyama. 2006. A comparative study of artificial neural networks and neuro-fuzzy in continuous modeling of the daily and hourly behaviour of runoff. Journal of Hydrology 337: 22-34.

Badmus, M. A., and O. S. Ariyo. 2011. Forecasting cultivated area and production of maize in Nigeria using ARIMA model. Asian Journal of Agricultural Sciences 3(3): 171-176, 2011.

Box, G.E.P. and G.M. Jenkin. 1976. Time Series of Analysis, Forecasting and Control, San Fransisco, Helden-Day, California. USA.

BPS. 2016. Laporan luas panen, produktivitas dan produksi jagung Indonesia tahun 1960-2016, Jakarta.

Cheng $\mathrm{CH}$, Huang SF, Teoh HJ. 2011. Predicting daily ozone concentration maxima using fuzzy time series based on a two-stage linguistic partition method. Comput Math Appl 62(4):2016-2028.

Darsana P 2012. Public-private Partnership on Maize Technology Development and Delivery: PT BISI International Experience and Overview. Proceeding of International Maize Conference, Gorontalo.

Ditjen PSP. 2017. Pedoman Pelaksanaan Pengadaan dan Penyaluran Bantuan Alat dan Mesin Pertanian APBN TA 2017. Direktotat Jenderal Prasarana dan Sarana Pertanian, Kementerian Pertanian: Jakarta

Egrioglu E, Aladag CH, Yolcu U, Basaran MA, Uslu VR. 2009. A new hybrid approach based on SARIMA and partial high order bivariate fuzzy time series forecasting model. Expert Syst Appl 36(4):7424-7434.
Enders, W. 2004. Applied econometric time series 2nd edition. New York: John Willey \& Sons, Inc.

Fatoki, O., U.A. Mbata, G.A. Olulude and O. Abass. 2010. An application of ARIMA model to Nigeria gross domestic production. Int. J. Stat. Sys., 5(1):310-320

Iqbal TA, Sadik K, dan SUmertajaya IM. 2014. Pemodelan Pengukuran Luas Panen Padi Nasional Menggunakan Generalized Autoregressive Conditional Heteroscedastic Model (GARCH). Penelitian Pertanian Tanaman Pangan Vol. 33 No. 12014

Kementerian Pertanian. 2016. Grand Design Produksi Jagung 2016-2045, Kementerian Pertanian: Jakar

Magar, R.B.; Jothiprakash. 2011. Intermittent reservoir daily-inflow prediction using lumped and distributed data multi-linear regression models. J. Earth Syst. Sci. 2011, 120, 10671084.

Matsumura, Gaitan CF, Sugimoto K, Alex JC and Hsieh W, 2014. Maize yield forecasting by linear regression and artificial neural networks in Jilin, China The Journal of Agricultural Science · May 2014.

Makridakis, Spyros, Wheelwright, Steven and Victor Mc Gee. 1999. Metode dan aplikasi peramalan (Edisi Bahasa Indonesia), $2^{\text {nd }}$ Edition. Erlangga Jakarta.

Murugan, N. \& Manivel, S. 2009. Profit planning of an NGO run enterprise using linear programming approach. International Research Journal of Finance and Economics, 23, 443-454

Musunuru, N, M. Yu, and A. Larson. 2013. Forecasting volatility of returns for corn using GARCH Models. The Texas Journal of Agriculture and Natural Resources. 26: 4255.

Nurmaulidar, Asep Rusyana, Rizka Maqfirah. 2016. Penggunaan metode exponential smoothing untuk meramalkan persediaan beras pada BULOG Divre Aceh. Prosiding SEMIRATA Bidang MIPA 2016; BKS-PTN Barat, Palembang 22-24 Mei 2016.

Okasha, K.M., Abu Shanab, M.M.D. 2014). Forecasting Monthly Water Production in Gaza City Using a Seasonal ARIMA Model Scholars Journal of Physics. Mathematics and Statistics, vol. 1, no. 2: 61-67.

Pusdatin. 2016. Outlook Komoditas Pertanian Sub Sektor Tanaman Pangan: Jagung. Pusat 
Data dan Sistem Informasi Pertanian, Kementerian Pertanian: Jakarta.

Pusdatin. 2017. Analisis Kinerja Perdagangan Jagung. Pusat Data dan Sistem Informasi Pertanian, Kementerian Pertanian, Jakarta.

Ranđelović, V., Prodanović, S., Despotović, S., Glamočlija Đ. 2010. Prinos kukuruza različitih FAO grupa zrenja u funkciji padavina tokom ASI perioda, Zbornik radova XXIV savetovanja agronoma, veterinara $i$ tehnologa. Beograd, vol. 16, no. 1-2, pp. 103111.

Sharda, R. and R. Patil, 1992. Connectionist Approach to Time Series Prediction: An Empirical Test, Journal of Intelligent Manufacturing, Forthcoming.

Sulaiman AA, Kariyasa IK, Hoerudin, Subagyono K, SUwandi dan Bahar, FA. 2017. Cara cepat swasembada jagung. Kementerian Pertanian 2017.

Tsaur, R. C., 2012. A Fuzzy Time Series-Markov Chain Model With An Application to Forecast The Exchange Rate Between the Taiwan and US Dollar. International Journal of Innovative Computing, Information, and Control Vol.8, No. 7.

Zheng, Y., H.W. Kinnucan, and H. Thompson. 2008. News and food price volatility. Applied Economics 40: 1629-1635.

\section{BIODATA PENULIS :}

Muhammad Aqil dilahirkan di Parepare, 6 Mei 1973. Menyelesaikan pendidikan S1 bidang Teknologi Pertanian Universitas Hasanuddin. Pendidikan S2 dan S3 diperoleh dari Universitas Gadjah Mada tahun 1999 dan Tottori University Japan tahun 2007.

Herman Subagio dilahirkan di Probolinggo 5 Juni 1960. Menyelesaikan pendidikan S1 Pemuliaan Universitas Brawijaya. Pendidikan S2 dan S3 diperoleh dari Universitas Gadjah Mada tahun 1992 dan IPB tahun 2008.

N. N. Andayani dilahirkan di Magetan 16 Juli 1984. Menyelesaikan pendidikan S1 bidang Pemuliaan Tanaman Universitas Brawijaya tahun 2007.

Fahdiana Tabri dilahirkan di Ujung Pandang 16 Juli 1965. Menyelesaikan pendidikan $\mathrm{S} 1$ bidang Agronomi Universitas Hasanuddin tahun 1990 dan pendidikan S2 bidang Sistem Pertanian Tahun 2004. 